\title{
Research Paper \\ The Pathology of Iran's Position in Global Doing Business Ranking According to General Policies
}

\author{
*Farhad Pahlevanzadeh ${ }^{1} \odot$, Elham Biabani² \\ 1. M.A. Faculty of Social Sciences, Allameh Tabatabaei University, Tehran, Iran. \\ 2. M.A. Faculty of Social Communication Sciences, Islamic Azad University, Central Tehran Branch, Tehran, Iran.
}

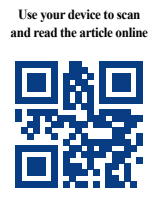

Cration: Pahlevanzadeh F \& Biabani E. (2020). [The Pathology of Iran's Position in Global Doing Business Ranking According to General Policies (Persian)]. Quarterly Journal of the Macro and Strategic Policies, 7(4), 612-629. https://doi.org/10.32598/JMSP.7.4.5

https://doi.org/10.32598/JMSP.7.4.5

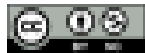

Received: 10 Dec 2019

Accepted: 27 Jan2019

Available Online: 01 Jan 202

Key words:

Business index, Business licenses, General employment policies, General policies of the sixth development plan

\section{ABSTRACT}

The World Bank annually ratings "Doing Business" in terms of improving the business environment of 190 countries, surveying private sector activists in each country, indicating ease of starting, maintaining and expanding business. The overall policies of the system, such as employment general policies, general policies of national production, support for the Iranian labor and capital, and Sixth Development Plan General Policies have emphasized the improvement of business conditions and the promotion of Iran's position. In this regard, this paper, by documentary method and based on World Bank's 2020 Doing Business Report, Iran's position in each of its sub-indices and components is compared with the first world countries and region in the same sub-index. Based on the results of the research, it was found that the major problem of Iran is related to the time and the number of stages of obtaining business licenses and the legal force of business rights. Based on the results of the research s the proposed strategies are presented in two areas: reduction of administrative bureaucracy and legal changes.

* Corresponding Author:

Farhad Pahlevanzadeh

Address: Department of Social Sciences, Faculty of Social Sciences, Allameh Tabatabaei University, Tehran, Iran.

Tel: +98 (21) 22258903

E-mail: f.pahlevanzadeh@yahoo.com 


\title{
آسيبشناسى جايكاه ايران در رتبهبندى جهانى شاخص انجام كسبوكار در راستاى سياستهاى كلى نظام
}

\author{
"فرهاد بهلوانزاده' •، الهام بيابانى'
}

ا. كارشناس ارشده دانشكده علوم اجتماعى دانشكاه علامه طباطبايى، تهران، ايران.

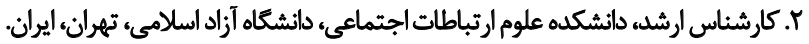

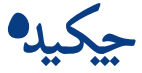

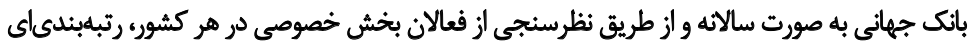

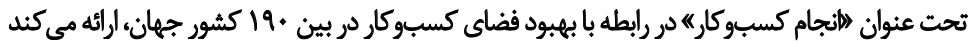

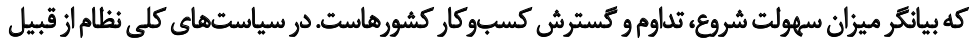

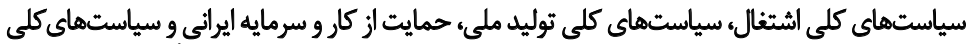

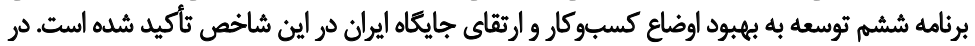

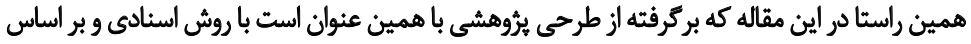

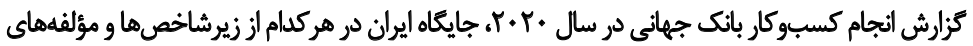

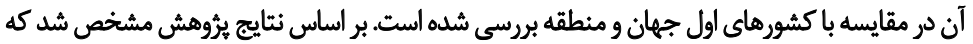

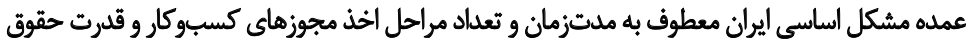

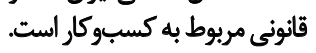

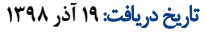

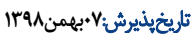

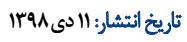

\section{:Logilguts}

شاخص انجام

كسبوكار،

مجوزماي كسبوكارك كار،

سياستهاي كلى ستي

اشتغال، سياستهاي كلي كائ

كلي برنامه ششيم سياسم

* *ويسنده مسئول:

فرهاد يهلوانزالده

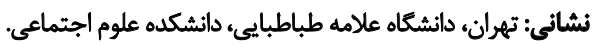

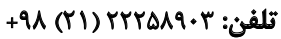

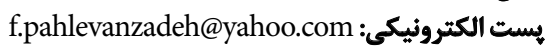




\section{مقدمه}

منظور از محيط كسبوكار، عوامل مؤثر بر عملكرد واحدهاى اقتصادى مانند كيفيت دستخاههاى حاكميت،

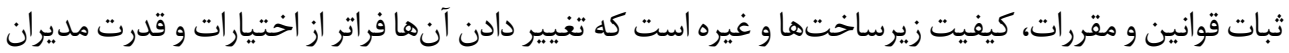

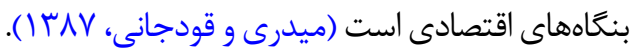

تجربه كشورهاى توسعهيافته و تحقيقات نهادهاى مختلف بينالمللى مانند بانك جهانى نشان داده است كه

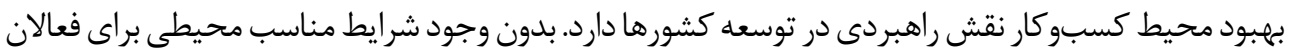

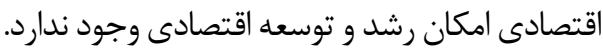
هدف از بهبود فضاى كسبوكار درواقع زمينهسازى قانونى و اجرايى براى فعاليت بهتر و بيشتر بخش

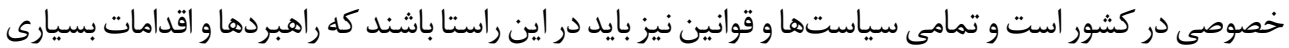

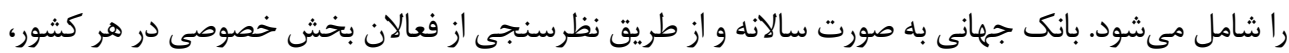

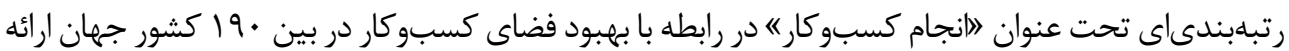
مى كند كه بيانكر ميزان سهولت شروع، تداوم و كسترش كسبون كار كار كشورهاست. شاخص 》انجام كسبو كار" از · ا زيرشاخص متفاوت و هر زيرشاخص از مؤلفههاى متعدد حوزههاى مختلف

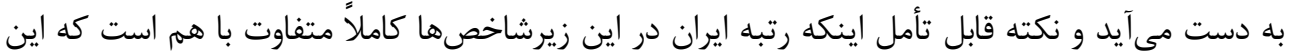

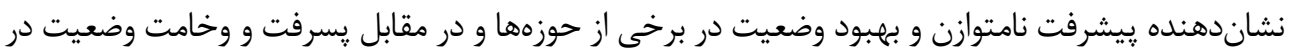

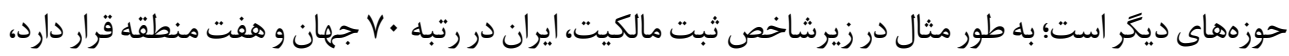

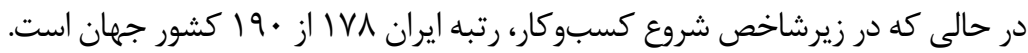

با توجه به تأثير رتبهبندى جهانى شاخص انجام كسبو كار در جذب سرمايهُذارى خارجى و نيز تغيير رويكرد

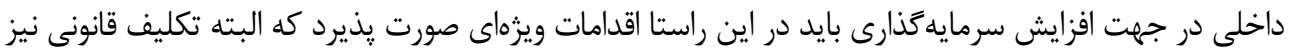

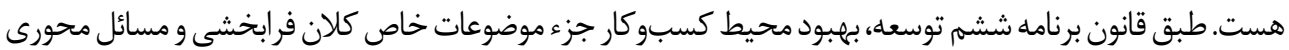

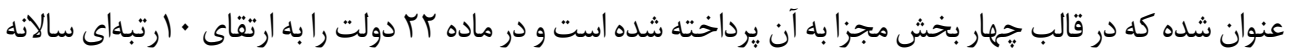

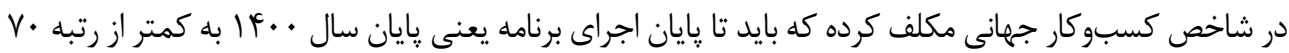

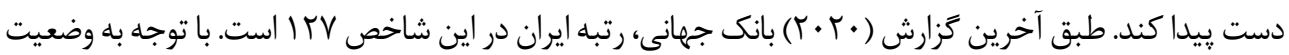

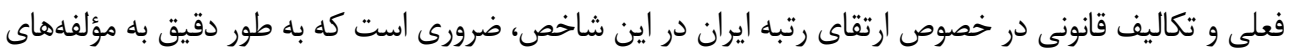

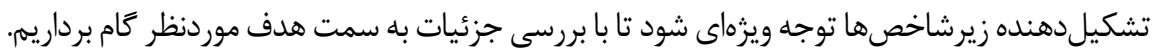

\section{| (اديات موضوع}

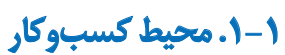

محيط كسبو كار، زمينهاى است كه بنعاه منابع موردنياز خود را از آن تقاضا و تأمين كرده و توليدات خود 


\section{بافت سياسى و}

اقتصادى كلان

\section{راهبرد و عمليات بنغاههاى اقتصادى}

$$
\text { محيط كسب و كار }
$$

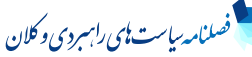

تصوير ا. نمودار عوامل اثركذار بر موفقيت شركتها منبع: (قزل اياغ و بهروزي، (IPFF)

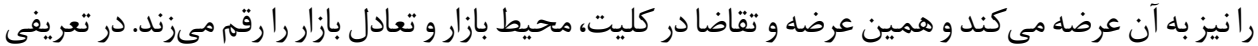

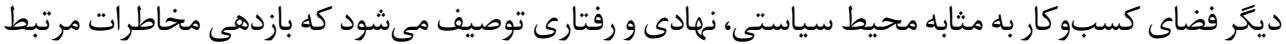

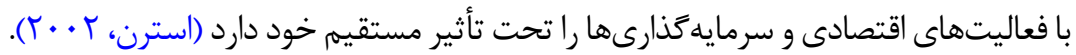
با توجه به تصوير شماره ا موفقيت بنگاههاى اقتصادى تابعى است از سه عامل به هم مرتبط: بافت سياسى

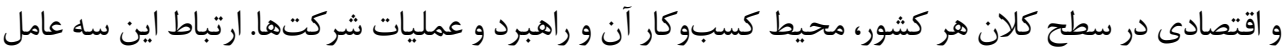

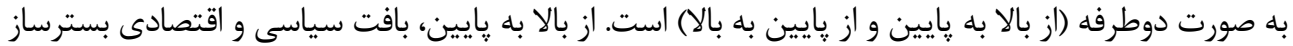

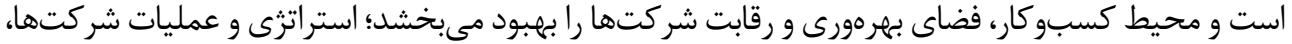

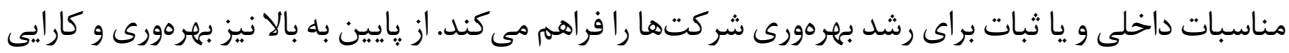

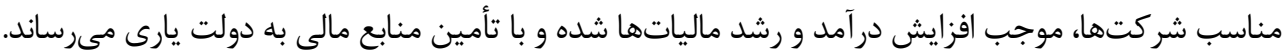

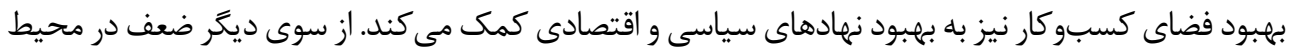

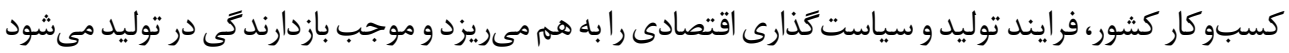

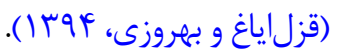

از جمله مهممترين نظريههاى جديدى كه انقلاب بزرگى در اقتصاد كشورهاى توسعهنيافته به پا كرد نظريه

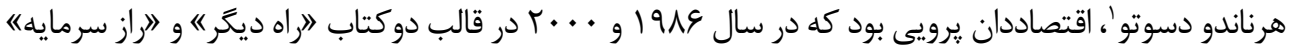

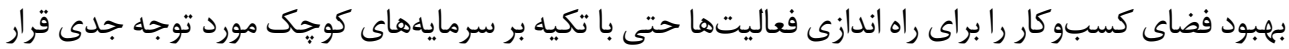

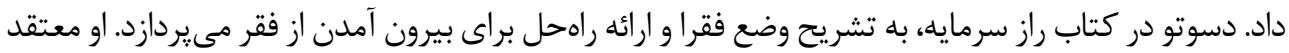

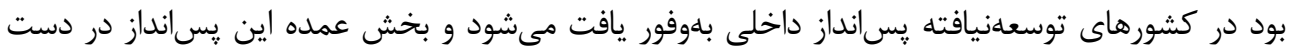

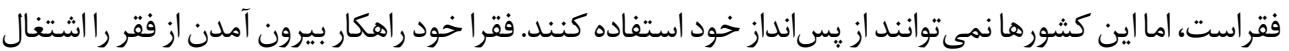

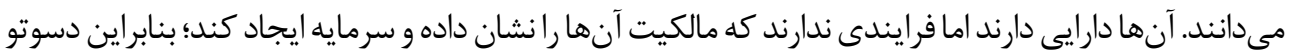

\section{Hernando de Soto}


تقويت نظام حقوق مالكيت خصوصى رابه عنوان يكى از اولين كامها براى بهببود فضاى كسبوكار و به دنبال آن

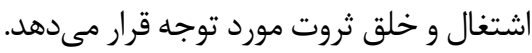

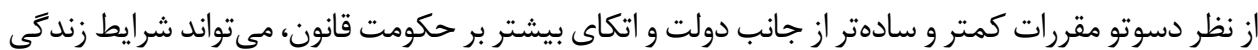

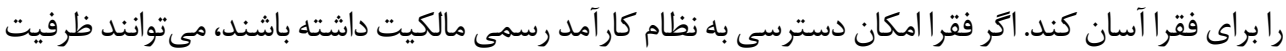

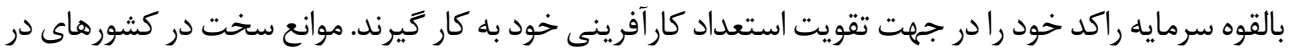

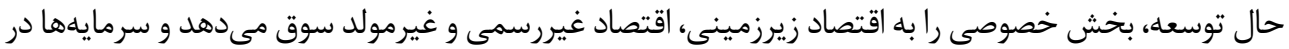

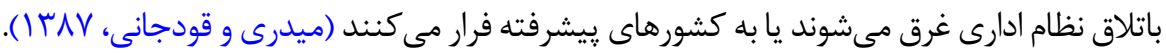

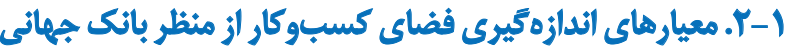

امروزه جندين مؤسسه بينالمللى، محيط كسبو كار در كشورهاى مختلف را راز نظر مؤلفههاى مختلف محيط

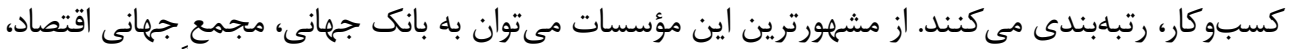

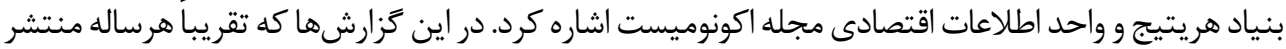

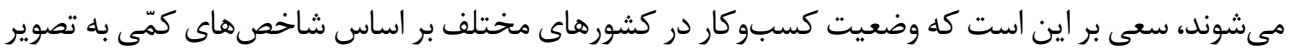

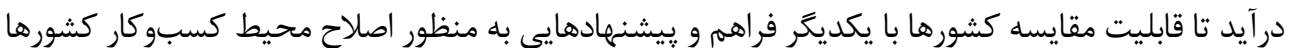
ارائه شود.

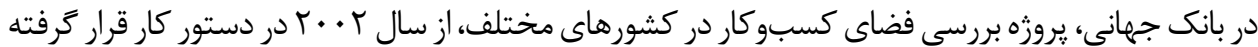

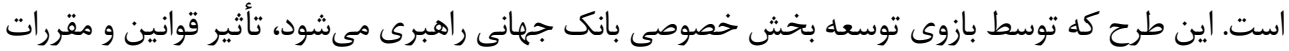

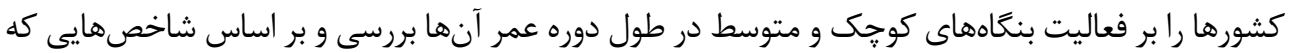

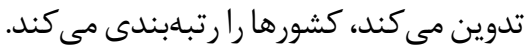

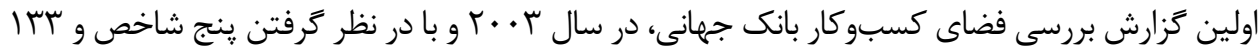

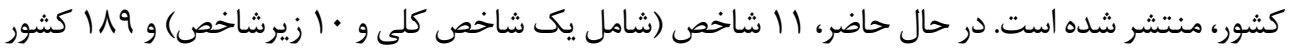

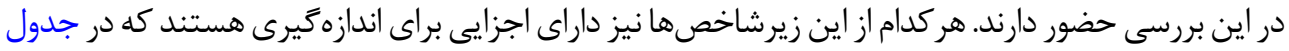

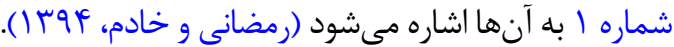

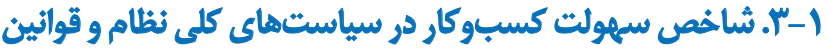

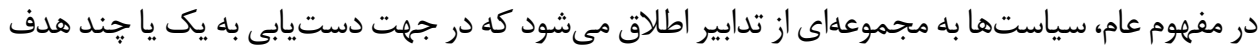

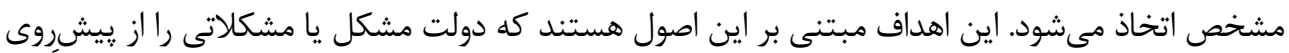

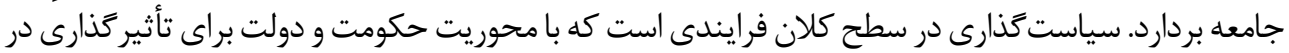

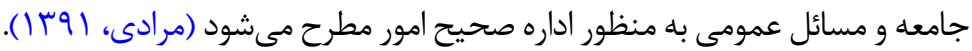
براى بهبود محيط كسبوكار و توسعه فعاليتهاى بخش خصوصى و تقويت توان رقابتى و رشد توليد، 
جدول 1. شاخص هاى كسبوكار بانك جهانى

\begin{tabular}{|c|c|}
\hline شبح & شاخص \\
\hline نشاندهنده رتبه كلى كشور & سهولت كسبوكار \\
\hline 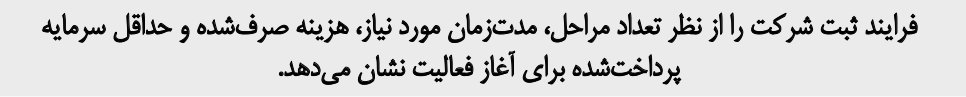 & شروع كسبوكار \\
\hline شامل تعداد مراحل، مدتزمان و هزينه صرفشده و غيره براى دريافت مجوزهاى موردنياز با استائدارد & اخذ مجوزهاى ساختمانى \\
\hline شامل تعداد مراحل، مدتزمان موردنياز و هزينه است. & 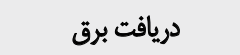 \\
\hline 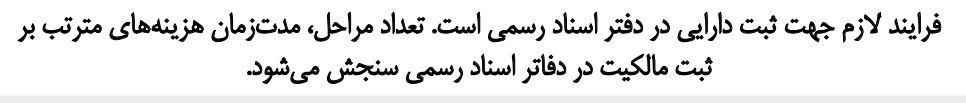 & ثُبت مالكيت \\
\hline 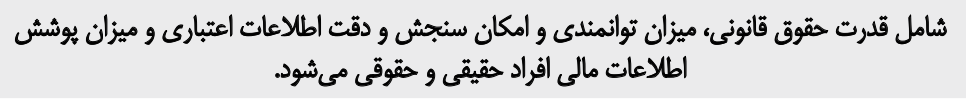 & اخذ اعتبار \\
\hline ميزان حمايت نهادهاى قانونى و رسمى ازٔ صاحبان سرمايه است، بلهخصوص در مواردى كه منافع مديران & حمايت از سرمايهكذاران \\
\hline 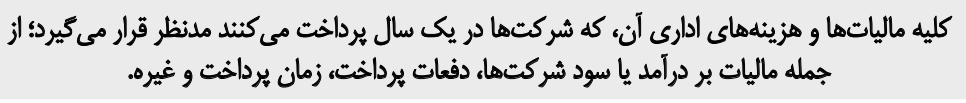 & 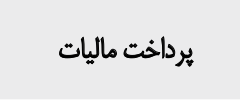 \\
\hline مدتزمان و هزينه مطابقت اسناد و مطابقت مرز صادرات و واردات است. & ت تجارت فرامزى \\
\hline شامل مدتزمان تشكيل و ابلاغ نتايج دادرسى و هزينه مترتب آن است. & اجراى قراردادها \\
\hline ميزان ضعف و قدرت قانون ورشكستكى كشورها و تنكئاهاى ادارى مربوط به فرايند ورشكستكى است. & حلوفصل ورشكستكى \\
\hline
\end{tabular}

״يشنيشازهاو ييششرطهايى وجود دارد. بر اين اساس اتخاذ تدابير لازم توسط بازيخران عرصه اقتصادى، بهويزه

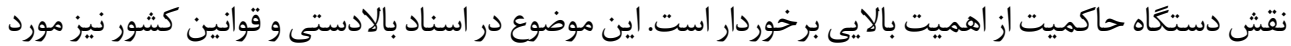

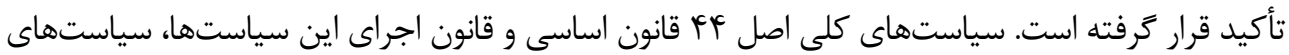

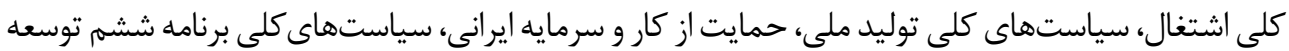

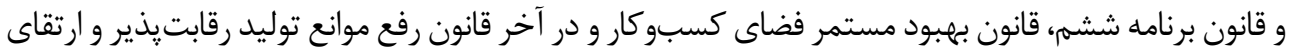

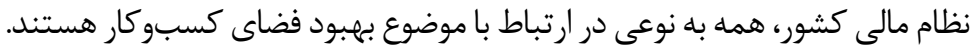

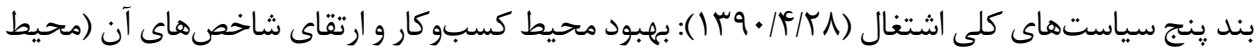

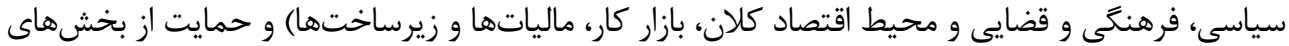

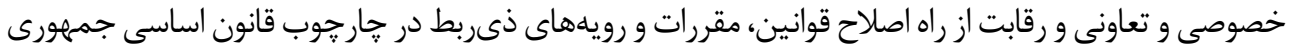
اسلامى ايران. 


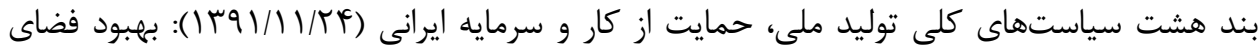

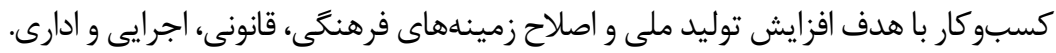

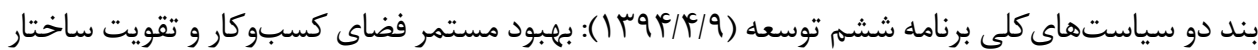
رقابتى و رقابتٍذيرى بازارها.

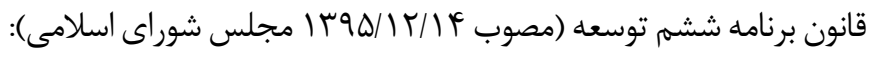

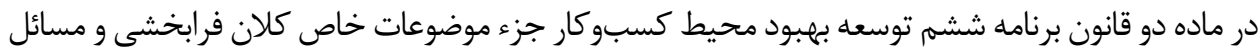

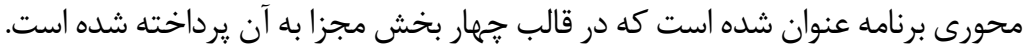

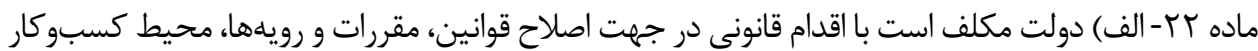

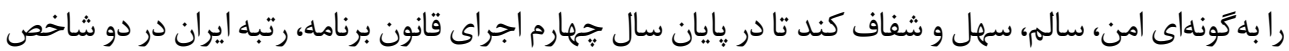

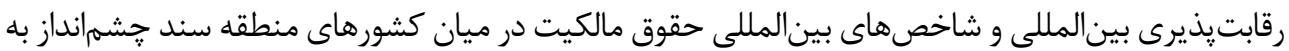

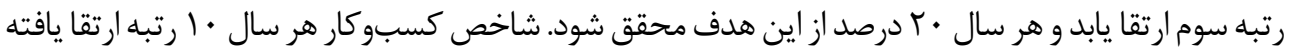

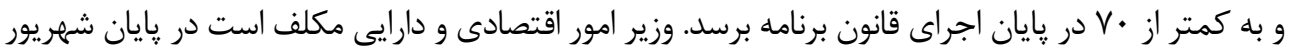

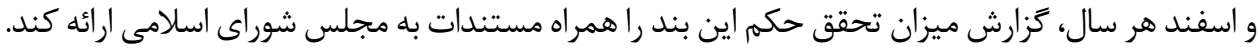

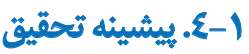

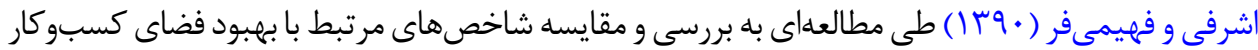

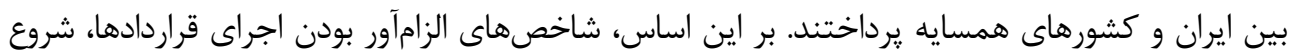

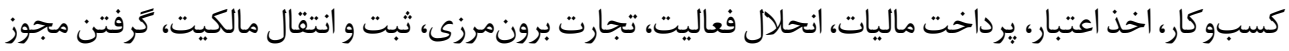

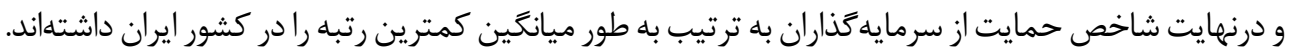

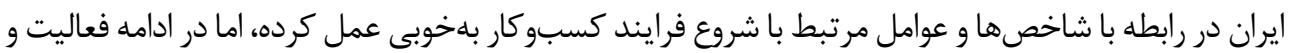

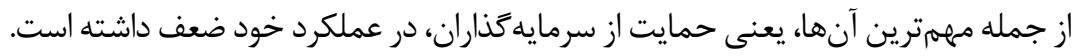

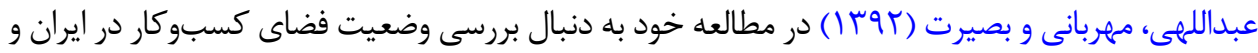

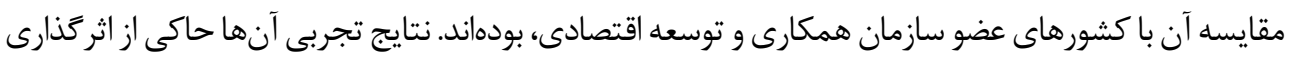

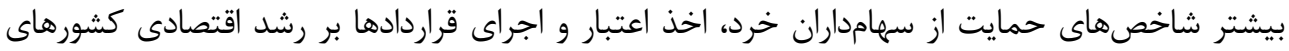

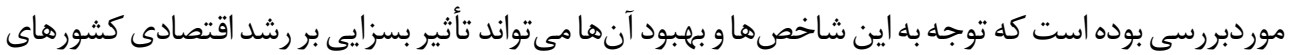
OECD داشته باشد.

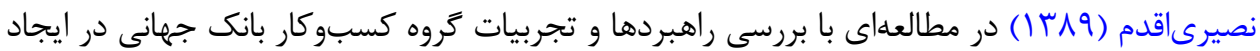

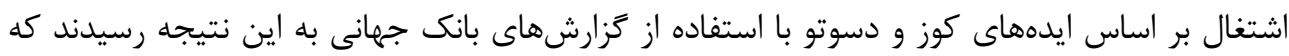

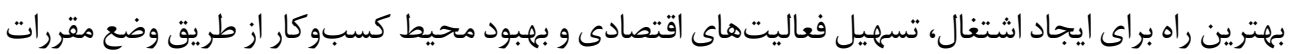
كمتر و كاراتر است. 


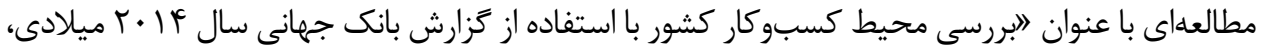

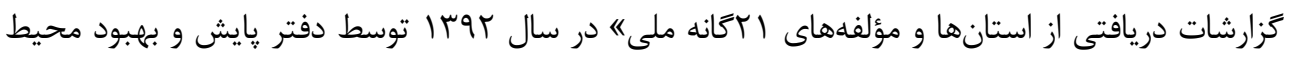

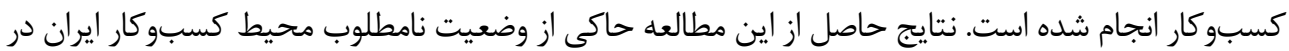

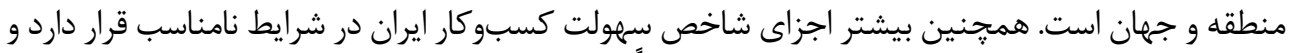

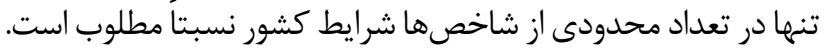

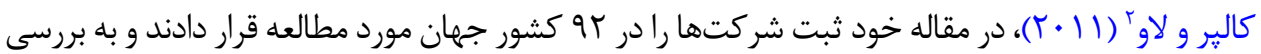

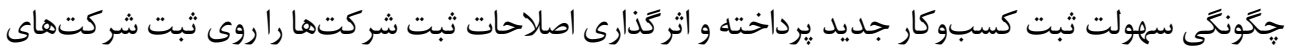

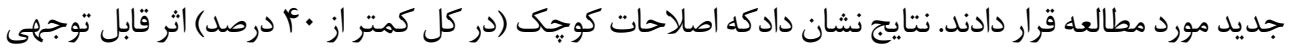

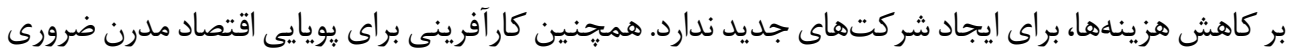
و با رشد اقتصادى مرتبط است.

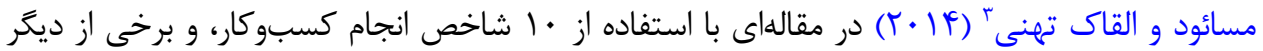

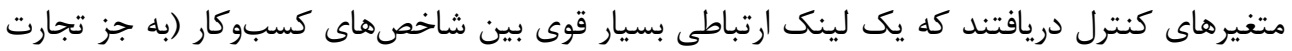

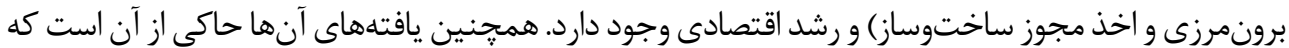

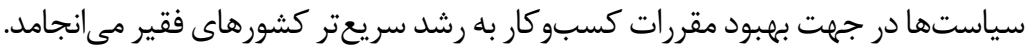

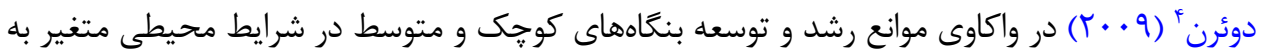

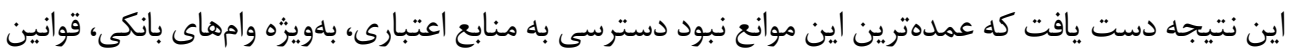

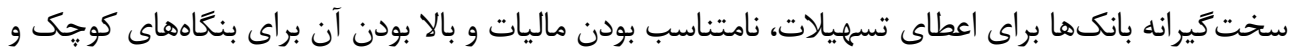

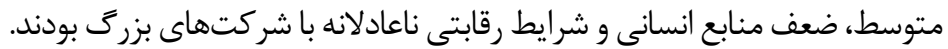

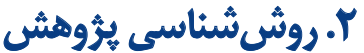

روش تحقيق در اين :روهش به صورت اسنادى است؛ بدين ترتيب بر اساس گزارش انجام كسبوكار بانك إنى

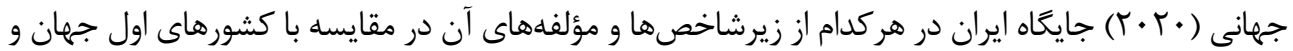
منطقه در همان زيرشاخص مورد بررسى قرار زرفته است.

\section{"ا. بافتههاى ثيزوهش}

زيرشاخص شروع كسبوكار فرايند ثبت شركت را از نظر تعداد مراحل، مدت زمان مورد نياز، هزينه صرف

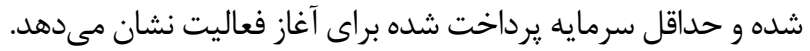
با توجه به جدول شماره r براى شروع يك كسبوكار در كشور نيوزلند كه در اين زيرشاخص رتبه اول جهان

2. Klapper \& Love

3. Messaoud \& El GhakTeheni

4. Doern 
جدول r. مقايسه ايران با رتبه يك جهان و منطقه در زيرشاخص شروع كسبوكار

\begin{tabular}{|c|c|c|c|c|c|c|}
\hline \multicolumn{2}{|c|}{ ايران } & \multicolumn{2}{|c|}{ امارات } & \multicolumn{2}{|c|}{ ن يوزلند } & \multirow{3}{*}{ زيرشاخص شروع كسبوكار } \\
\hline IVA & رتبه & iv & رتبه & 1 & رتبه & \\
\hline TV/A & امتياز & $9 \varepsilon / \wedge$ & المتياز & $1++$ & امتياز & \\
\hline \multicolumn{2}{|c|}{1.} & \multicolumn{2}{|c|}{$r$} & \multicolumn{2}{|c|}{1} & ت تعداد مراحل \\
\hline \multicolumn{2}{|c|}{$n$} & \multicolumn{2}{|c|}{$r / \Delta$} & \multicolumn{2}{|c|}{.$/ \Delta$} & مدتزمان (روز) \\
\hline \multicolumn{2}{|c|}{ m } & \multicolumn{2}{|c|}{$I V / \pi$} & \multicolumn{2}{|c|}{.$/ r$} & هزينه (درصد از درآهد سراثه) \\
\hline \multicolumn{2}{|c|}{ - } & \multicolumn{2}{|c|}{. } & \multicolumn{2}{|c|}{. } & حداقل سرمايه يرداختشده \\
\hline
\end{tabular}

ب

-World Bank Group, Doing Business 2020

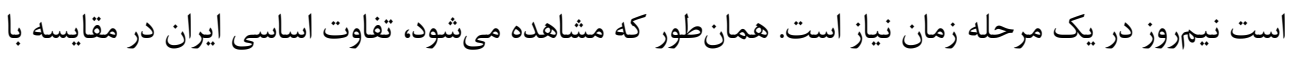

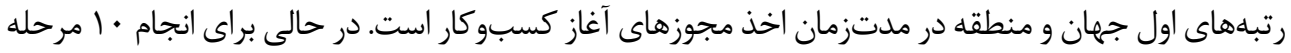

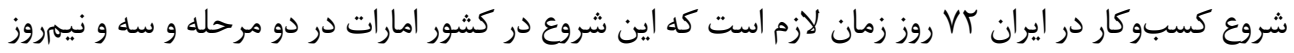

جدول r. مقايسه ايران با رتبه يك جهان و منطقه در زيرشاخص مجوز ساختوساز

\begin{tabular}{|c|c|c|c|c|c|c|}
\hline \multicolumn{2}{|c|}{ ايران } & \multicolumn{2}{|c|}{ امارات } & \multicolumn{2}{|c|}{ هنكئك } & \multirow{3}{*}{ زيرشاخص مجوز ساختوساز } \\
\hline$n$ & رتبه & $r$ & رتبه & 1 & رتبه & \\
\hline$V I / r$ & امتياز & $94 / 1$ & 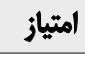 & $9 \% / 0$ & 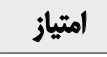 & \\
\hline \multicolumn{2}{|c|}{18} & \multicolumn{2}{|c|}{11} & \multicolumn{2}{|c|}{$\wedge$} & ت تعداد مراحل \\
\hline \multicolumn{2}{|c|}{ ir. } & \multicolumn{2}{|c|}{$F / \Delta$} & \multicolumn{2}{|c|}{99} & مدتزمان (روز) \\
\hline \multicolumn{2}{|c|}{$8 / 4$} & \multicolumn{2}{|c|}{$T / T$} & \multicolumn{2}{|c|}{.$/ 4$} & هزئنه (درصد از ارزش مكان) \\
\hline \multicolumn{2}{|c|}{$\mid r / \Delta$} & \multicolumn{2}{|c|}{10} & \multicolumn{2}{|c|}{ is } & شاخص كثترل كيفيت ساختمان (ها-·) \\
\hline \multicolumn{2}{|c|}{ r } & \multicolumn{2}{|c|}{ r } & \multicolumn{2}{|c|}{ r } & شاخص كيفيت هقررات ساختمان (Y-•) \\
\hline \multicolumn{2}{|c|}{1} & \multicolumn{2}{|c|}{1} & \multicolumn{2}{|c|}{1} & شاخص كتترل كيفيت قبل از ساختوساز (1-·) \\
\hline \multicolumn{2}{|c|}{$r$} & \multicolumn{2}{|c|}{ r } & \multicolumn{2}{|c|}{$r$} & شاخص كتترل كيفيت در طول ساختوساز (ب-·) \\
\hline \multicolumn{2}{|c|}{$1 / \Delta$} & \multicolumn{2}{|c|}{ r } & \multicolumn{2}{|c|}{ r } & شاخص كنترل كيفيت بعد از ساختوساز (ب-·) \\
\hline \multicolumn{2}{|c|}{$1 / \Delta$} & \multicolumn{2}{|c|}{ r } & \multicolumn{2}{|c|}{ r } & ساختارهاي مسئوليت و بيمه (T-·) \\
\hline \multicolumn{2}{|c|}{ f } & \multicolumn{2}{|c|}{ f } & \multicolumn{2}{|c|}{ r } & شاخص كواهى نامههاي حرفهاي ([أ-·) \\
\hline
\end{tabular}


جدول F. مقايسه ايران با رثبه يك جهان در زيرشاخص دريافت برث

\begin{tabular}{|c|c|c|c|c|}
\hline \multicolumn{2}{|c|}{ 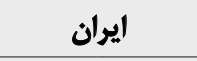 } & \multicolumn{2}{|c|}{ المارات } & \multirow{3}{*}{ زيرشاخص دريافت برق } \\
\hline Mr & رتبه & 1 & رتبه & \\
\hline $79 / \varepsilon$ & 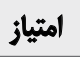 & $1+4$ & 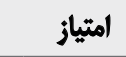 & \\
\hline 8 & & & r & تعلعاد مراحل \\
\hline$w$ & & & $\checkmark$ & 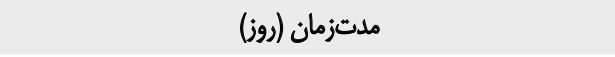 \\
\hline Vie & & & $\cdot$ & هزينه (مر صد أز درآمد سرائه) \\
\hline$\Delta$ & & & $A$ & شاخص قابليت اطمينان در عرضه و شفافيت تعرفه (A-•) \\
\hline 1 & & & $r$ & شاخص مدت زمان و دفعات خاموشى هر مشترك در سال (ب--) \\
\hline 1 & & & 1 & مكانيسم نظارت بر قطع (1-+) \\
\hline 1 & & & 1 & هكانيسم بازيانى خدمات (1--) \\
\hline 1 & & & 1 & كتترل تنظيم (1-•) \\
\hline$\cdot$ & & & 1 & بازدارندههاى مالى قطعى برق (1-+) \\
\hline 1 & & & 1 & تغييرات تعرفهاي (1- .) \\
\hline$\checkmark$ & & & . /Rם & شاخص متوسط مدتزمان وقفه سيستم (ساعت در سال) \\
\hline$\Delta / r$ & & & $\cdot / \pi f$ & شاخص ميانكين تعلاد وقفه سيستم (دفعه در سال) \\
\hline$\Delta$ & & & $\Delta$ & حلاقل زمان خاموشى (دقيقه) \\
\hline$\Delta / \tau$ & & & $1 . / 9$ & قيمت برق (سنت در هر كيلووات ساعت) \\
\hline
\end{tabular}

(1)

-World Bank Group, Doing Business 2020

اتفاق مىافتد. با توجه به اطلاعات جدول شماره ب مىتوان نتيجه گَرفت كه براى ارتقاى جايگاه ايران در اين

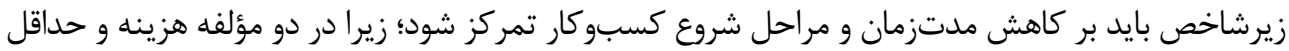

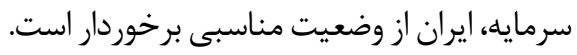
زيرشاخص مجوز ساختوساز شامل تمامى فرايندهاى لازم براى اخذ مجوزهاى موردنياز تا تأسيس و راهاندازى

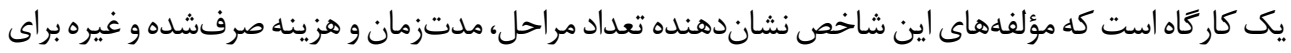

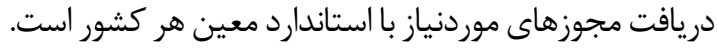
رتبه س Vايران در زيرشاخص مجوز ساختوساز تقريباً قابل قبول است. تفاوت فاحش ايران در مؤلفههاى اين

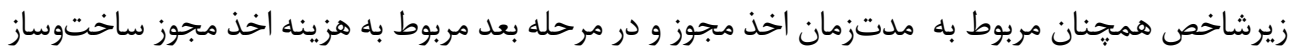

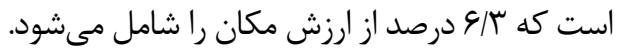


جدول هـ مقايسه ايران با رثبه يك جهان در زيرشاخص ثبت مالكيت

\begin{tabular}{|c|c|c|c|c|}
\hline \multicolumn{2}{|c|}{ اليران } & \multicolumn{2}{|c|}{ قطر } & \multirow{3}{*}{ زيرشاخص ثبت مالكيت } \\
\hline V. & رتبه & 1 & رتبه & \\
\hline W/1 & 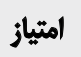 & $97 / \%$ & 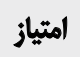 & \\
\hline \multicolumn{2}{|c|}{8} & \multicolumn{2}{|c|}{1} & تعداد مراحل \\
\hline \multicolumn{2}{|c|}{$m$} & \multicolumn{2}{|c|}{1} & مدتزمان (يوز) \\
\hline \multicolumn{2}{|c|}{$r / A$} & \multicolumn{2}{|c|}{$/ r$} & هزينه (درصد از ارزش ملك) \\
\hline \multicolumn{2}{|c|}{ is } & \multicolumn{2}{|c|}{ re } & شاخص كيفيت مديريت اراضي (•r-•) \\
\hline \multicolumn{2}{|c|}{8} & \multicolumn{2}{|c|}{$\wedge$} & شاخص اطمينان از زيرساختها (A-•) \\
\hline \multicolumn{2}{|c|}{1} & \multicolumn{2}{|c|}{$\Psi / \Delta$} & شاخص شفافيت اطلاعات (و-+) \\
\hline \multicolumn{2}{|c|}{ f } & \multicolumn{2}{|c|}{$\wedge$} & شاخص يوشش جغرافيايى (A-+) \\
\hline \multicolumn{2}{|c|}{$\Delta$} & \multicolumn{2}{|c|}{$9 / \Delta$} & شاخص حل اختلاف زمين (1-+) \\
\hline \multicolumn{2}{|c|}{ • } & \multicolumn{2}{|c|}{ * } & شاخص دسترسى برابر به حقوق مالكيت (•-Y-) \\
\hline
\end{tabular}

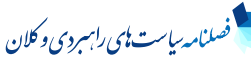

World Bank Group, Doing Business 2020

در زيرشاخص دريافت برق رتبه اول جهان متعلق به كشور امارات از منطقه خاورميانه است. همان طور كه در

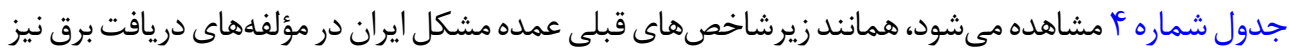

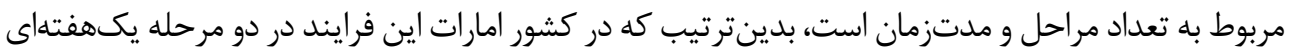

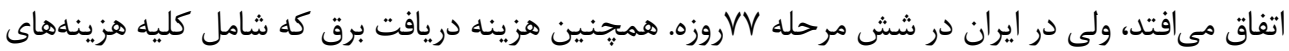

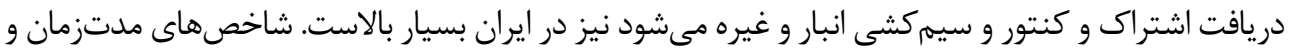

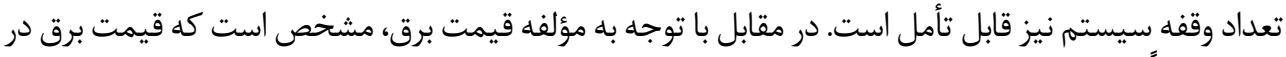

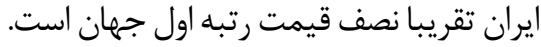

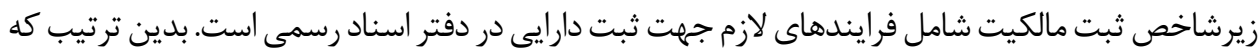

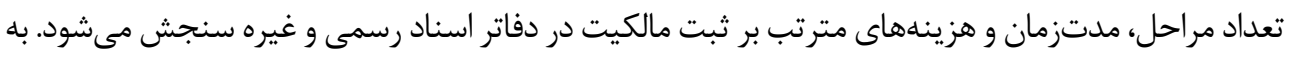

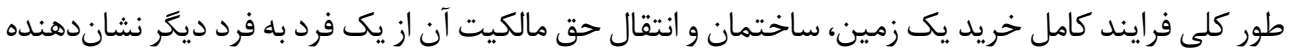
امتياز اين شاخص است (جدول شماره ه).

در زيرشاخص ثبت مالكيت نيز همجنان مسئله تعداد مراحل و مدتزمان در خصوص ايران پابرجاست، بـ دابه

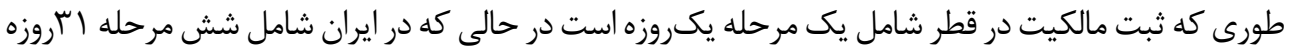

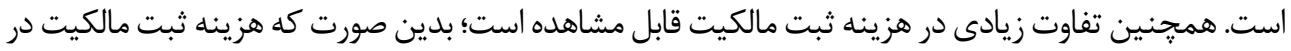

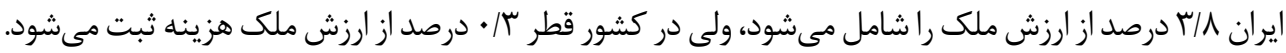


جدول و. مقايسه ايران با رتبه يك جهان و منطقه در زيرشاخص دريافت اعتبار

\begin{tabular}{|c|c|c|c|c|c|c|}
\hline \multicolumn{2}{|c|}{ ايران } & \multicolumn{2}{|c|}{ إرن } & \multicolumn{2}{|c|}{ نيوزلند } & \multirow{3}{*}{ زيرشاخص درياقت اعتبار } \\
\hline $1+\varepsilon$ & رتبه & $\varepsilon$ & رتبه & 1 & رتبه & \\
\hline o. & 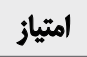 & 90 & امتياز & $1+$ & 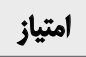 & \\
\hline \multicolumn{2}{|c|}{ r } & \multicolumn{2}{|c|}{11} & \multicolumn{2}{|c|}{ ir } & شاخص قدرت حقوق قائونى (IT-•) \\
\hline \multicolumn{2}{|c|}{$\wedge$} & \multicolumn{2}{|c|}{$\wedge$} & \multicolumn{2}{|c|}{$\wedge$} & شاخص دقت اطلاعات اعتبارى (1-•) \\
\hline \multicolumn{2}{|c|}{1.} & \multicolumn{2}{|c|}{19} & \multicolumn{2}{|c|}{ r. } & امتياز كل دريافت اعتبار (مجموع امتياز دو شاخص) \\
\hline \multicolumn{2}{|c|}{$8 \cdot / r$} & \multicolumn{2}{|c|}{$\Delta$} & \multicolumn{2}{|c|}{ • } & يوثش ثبت اعتبارى - دولتى (درصدى از بزركسالان) \\
\hline \multicolumn{2}{|c|}{$8 \cdot N$} & \multicolumn{2}{|c|}{$r r / q$} & \multicolumn{2}{|c|}{$1 \ldots$} & يوشش دفتر اعتبارى ـ خصوصى (درصدى از بزركسالان) \\
\hline
\end{tabular}

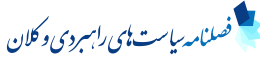

World Bank Group, Doing Business 2020

جدول V. مقايسه ايران با رتبه يك جهان و منطقه در زيرشاخص حمايث از سرمايهكذاران خرد

\begin{tabular}{|c|c|c|c|c|c|c|}
\hline \multicolumn{2}{|c|}{ 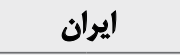 } & \multicolumn{2}{|c|}{ عريستان سعودى } & \multicolumn{2}{|c|}{ كنيا } & \multirow{3}{*}{ زيرشاخص حمايت از سرمايهكذاران خرد } \\
\hline irs & رتبه & $r$ & 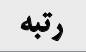 & 1 & رتبه & \\
\hline$\varepsilon$ & المثياز & A7 & 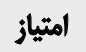 & ar & امتياز & \\
\hline \multicolumn{2}{|c|}{$\gamma$} & \multicolumn{2}{|c|}{9} & \multicolumn{2}{|c|}{1.} & شاخص ميزان اقشاى اطلاعات (+1-•) \\
\hline \multicolumn{2}{|c|}{ f } & \multicolumn{2}{|c|}{9} & \multicolumn{2}{|c|}{1.} & شاخص ميزان مسئوليت مدير (•|-•) \\
\hline \multicolumn{2}{|c|}{1} & \multicolumn{2}{|c|}{$\gamma$} & \multicolumn{2}{|r|}{9} & شاخص سهولت شكايت سهامداران (+(1-+) \\
\hline \multicolumn{2}{|c|}{ r } & \multicolumn{2}{|c|}{$\Delta$} & \multicolumn{2}{|r|}{8} & شاخص ميزان حقوق سهامداران (ه-+) \\
\hline \multicolumn{2}{|c|}{$r$} & \multicolumn{2}{|c|}{8} & \multicolumn{2}{|c|}{$\varepsilon$} & شاخص ميزان مالكيت و كنترل (V-+) \\
\hline \multicolumn{2}{|c|}{ r } & \multicolumn{2}{|c|}{$v$} & \multicolumn{2}{|r|}{$\Delta$} & شاخص ميزان شفافيت شركت (V-+) \\
\hline \multicolumn{2}{|c|}{ r. } & \multicolumn{2}{|c|}{ r } & \multicolumn{2}{|c|}{ te } & شاخص قدرت حمايت أز سرمايهكذاران خرد (•ه-+) \\
\hline
\end{tabular}

در زيرشاخص دريافت اعتبار، قدرت حقوق قانونى، ميزان توانمندى و امكان سنجش و دقت اطلاعات اعتبارى

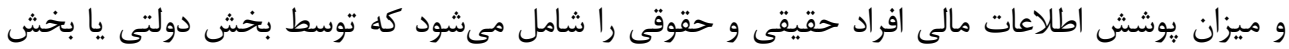

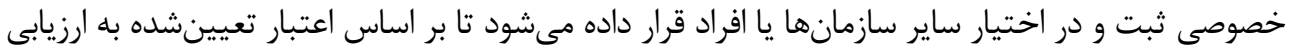
فعالان اقتصادى بيردازند.

در زيرشاخص دريافت اعتبار ايران از لحاظ دقت و عمق اطلاعات اعتبارى همتراز كشورهاى اول جهان و منطقه است كه موقعيتى بسيار عالى است، ولى در شاخص قدرت حقوق قانونى در مقايسه با اين كشورها 
ضعيف است كه متناسب آن، تأثير منفى در امتياز كل دريافت اعتبار قابل مشاهده است.

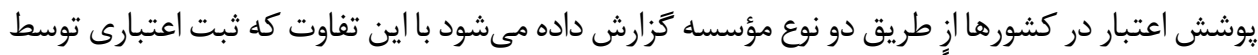

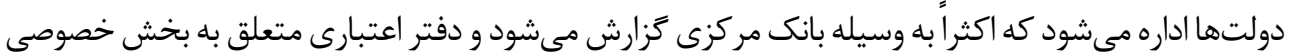

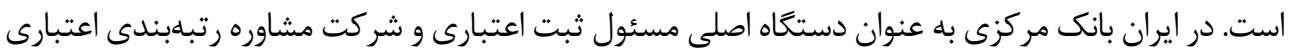

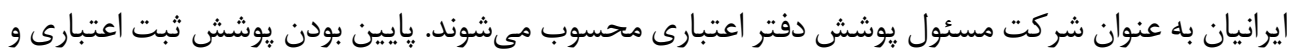

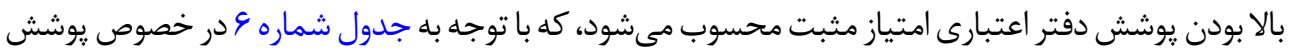

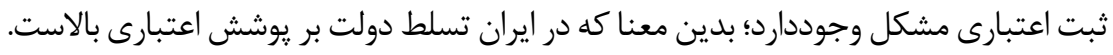

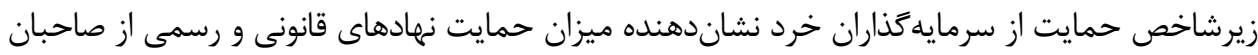

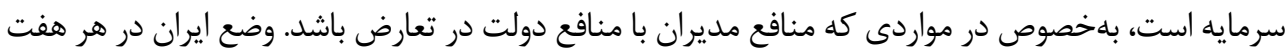

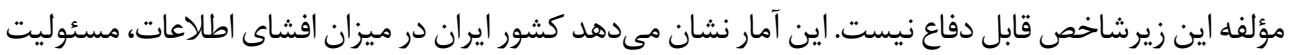

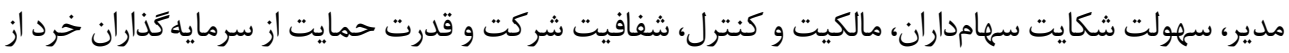
وضع مطلوبى برخور دار نيست (جدول شماره V (V).

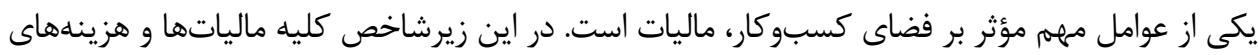

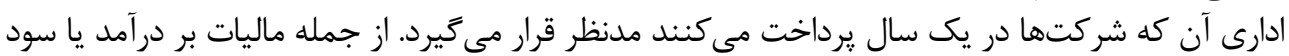

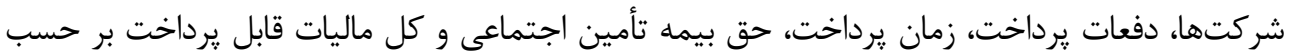

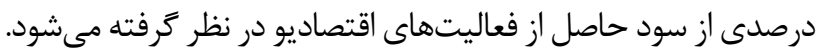

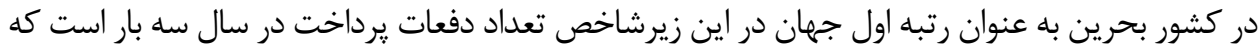

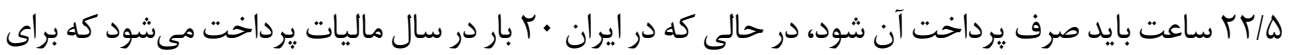

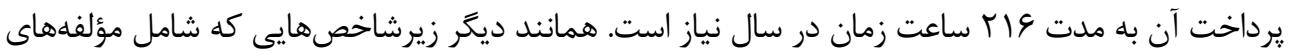

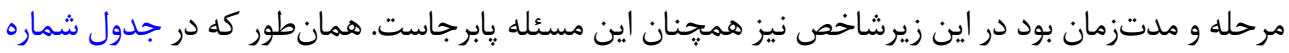

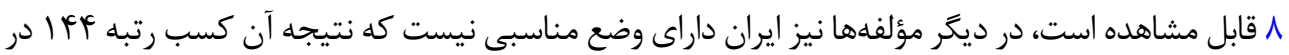
اين زيرشاخص است.

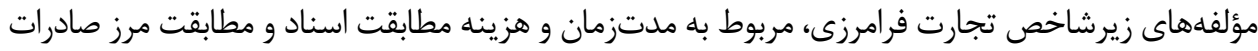

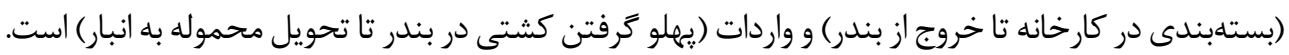

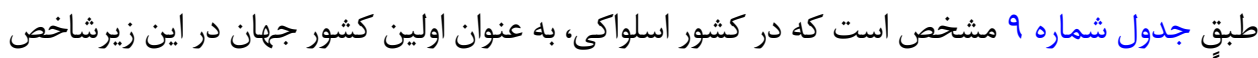

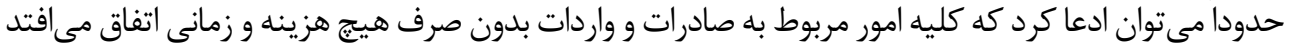

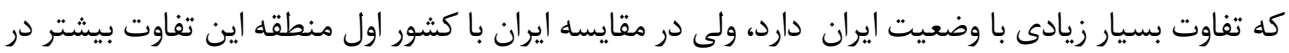

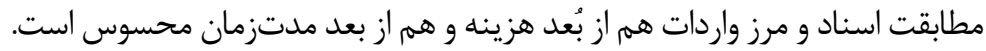

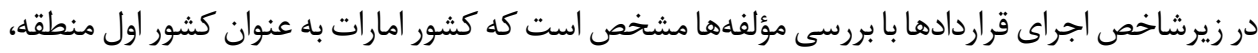

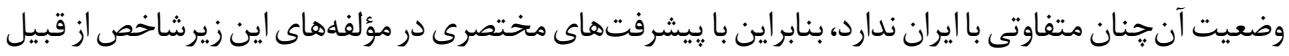


جدول ^. مقايسه ايران با رتبه يك جهان و منطقه در زيرشاخص يرداخت ماليات

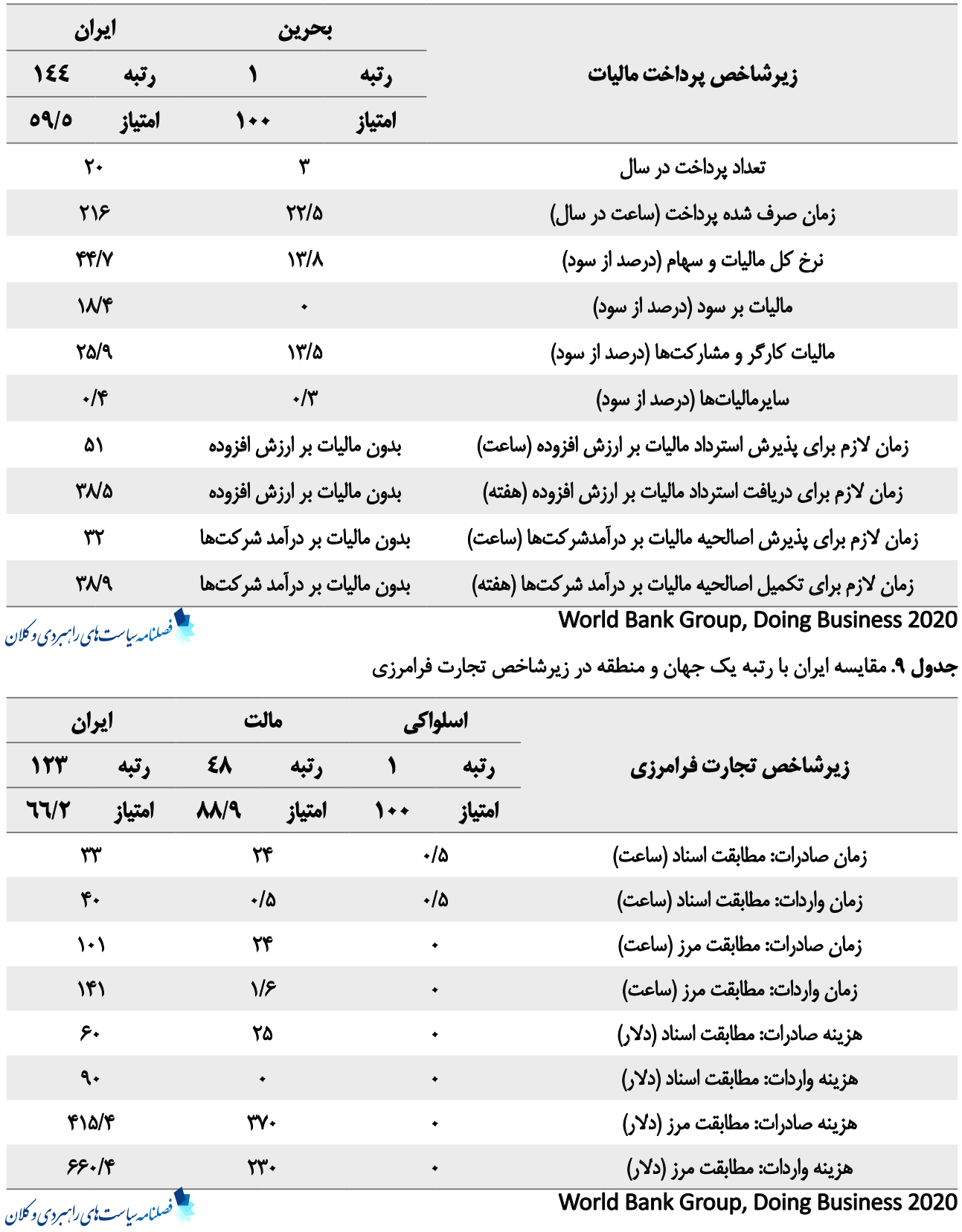




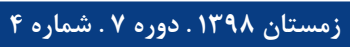

جدول +1. مقايسه ايران با رثبه يك جهان و منطقه در زيرشاخص اجراى قراردادها

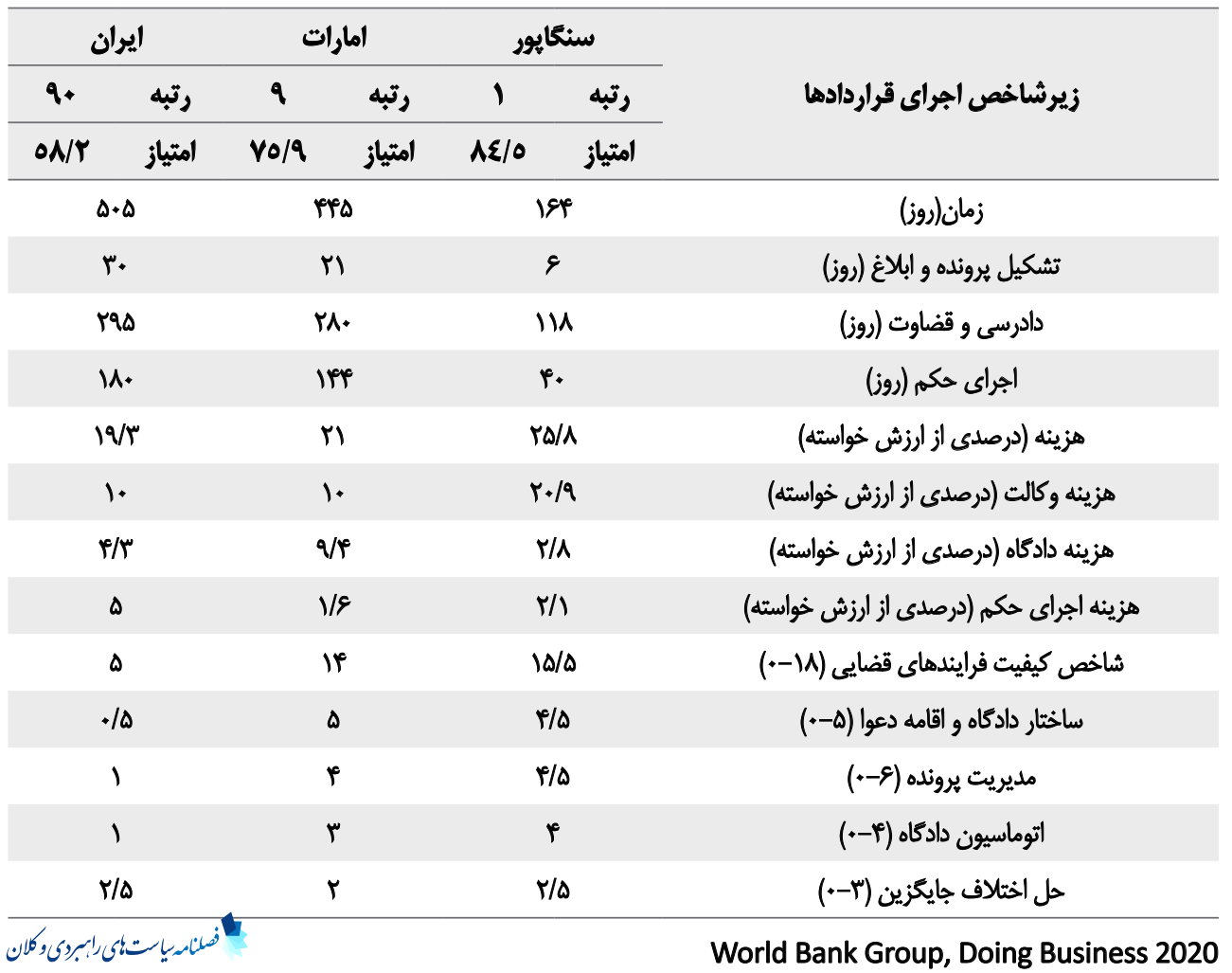

كيفيت فرايندهاى قضايى، ساختار دادكاه و مديريت يرونده مىتوان به موقعيت مناسبى در اين زيرشاخص

$$
\text { رسيد (جدول شماره • (1). }
$$

زيرشاخص حلوفصل ورشكستگى بيانگر ميزان ضعف و قدرت قانون ورشكستگى كشورها و تنگَناهاى ادارى مربوط به فرايند ورشكستخى است. با توجه به جدول جئ شماره

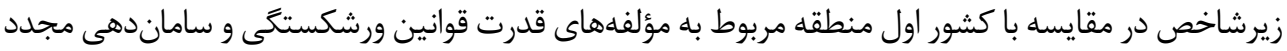

فرايند رسيدگى است.

ع

با اذعان به اينكه در آمار نهادهاى بينالمللى در حوزه برخى شاخصهاى سياسى، اقتصادى و اجتماعى اغراض

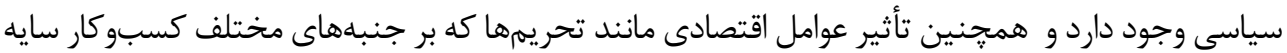

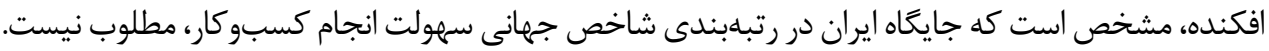

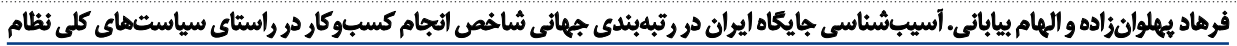

grg 
جدول Iا. مقايسه ايران با رتبه يك جهان و منطقه در زيرشاخص حلوفصل ورشكستكى

\begin{tabular}{|c|c|c|c|c|c|c|}
\hline \multicolumn{2}{|c|}{ 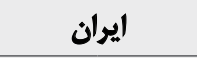 } & \multicolumn{2}{|c|}{ جيبوتي } & \multicolumn{2}{|c|}{ فنالدي } & \multirow{3}{*}{ زيرشاخص حلوفصل ورشكستيّى } \\
\hline im & رتبه & $\varepsilon \varepsilon$ & رتبه & 1 & رتبه & \\
\hline $\mathrm{ro/l}$ & 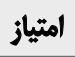 & $70 / 9$ & 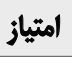 & Qr/V & 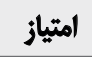 & \\
\hline \multicolumn{2}{|c|}{$1 / 0$} & \multicolumn{2}{|c|}{$1 / \Delta$} & \multicolumn{2}{|c|}{.$/ 9$} & زمان (سالل) \\
\hline \multicolumn{2}{|c|}{10} & \multicolumn{2}{|c|}{11} & \multicolumn{2}{|c|}{$m / Q$} & هزينه (درصدى از دارايیى) \\
\hline \multicolumn{2}{|c|}{ rep } & \multicolumn{2}{|c|}{ pf } & \multicolumn{2}{|c|}{$M$} & نرح بازستانى (احياى بنكاه اقتصادى) (سنت در هر دلار) \\
\hline \multicolumn{2}{|c|}{$\Delta$} & \multicolumn{2}{|c|}{$1 \% / \Delta$} & \multicolumn{2}{|c|}{$1 \% / \Delta$} & شاخص قدرت قوائين ورشكستكى (عا-•) \\
\hline \multicolumn{2}{|c|}{$r$} & \multicolumn{2}{|c|}{$r / \Delta$} & \multicolumn{2}{|c|}{$r$} & شاخص طرح دعوا (ب-+) \\
\hline \multicolumn{2}{|c|}{ r } & \multicolumn{2}{|c|}{$\Delta / \Delta$} & \multicolumn{2}{|c|}{8} & شاخص مديريت دارايىهاى بدهكار (9-+) \\
\hline \multicolumn{2}{|c|}{ - } & \multicolumn{2}{|c|}{$V / \Delta$} & \multicolumn{2}{|c|}{$r / \Delta$} & شاخص ساماندهى مجدد فرايند رسيدكى ("ا-4) \\
\hline \multicolumn{2}{|c|}{1} & \multicolumn{2}{|c|}{ r } & \multicolumn{2}{|c|}{$r$} & شاخص مشاركت طلبكار (Y-**) \\
\hline
\end{tabular}

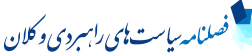

-World Bank Group, Doing Business 2020

بر اساس نتايج اين يثرهش با بررسى دادههاى اسنادى بانك جهانى و شاخصهاى كمّى سهولت انجام

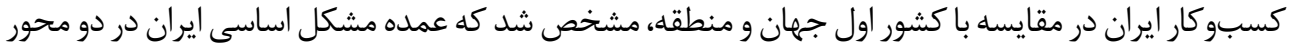
مدتزمان و تعداد مراحل اخذ مجوزهاى كسبوكار و قدرت حقوق قانونى مربوط به كسبو كار كار است. مؤلفه تعداد مراحل و مدتزمان: اين مؤلفه در هشت زيرشاخص از · ا زيرشاخص سهولت انجام كسبوكار

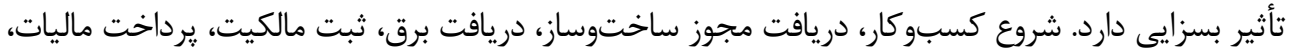

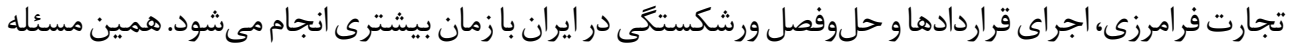

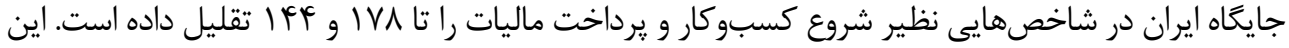

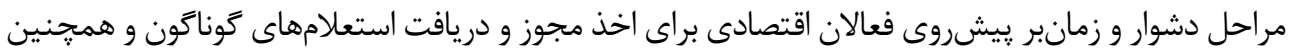

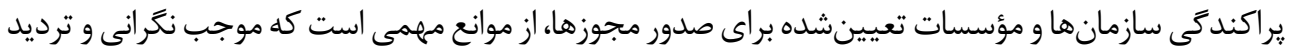

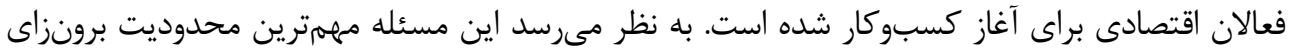

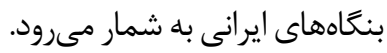

راهكارهاى عملياتى كه براى برطرف كردن اين مشكل مىتوان ييشنهراد كرد معطوف به كاهش بوروكراسى

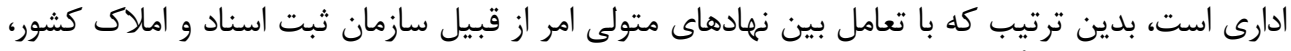

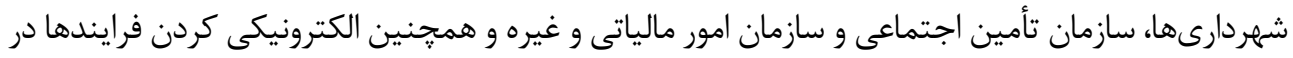

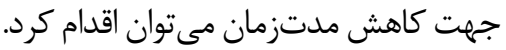
مؤلفه قدرت حقوق قانونى: ايران از لحاظ قدرت حمايت از سرمايهگذاران خرد و قدرت در حقوق قانونى 
دريافت اعتبار، از وضع مطلوبى برخوردار نيست. در خصوص دريافت اعتبار، مطالبات معوق بانكها موجب

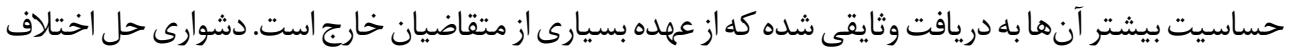
تجارى و وصول مطالبات و ضعف قوانين ورشكستكى نيز مؤيد ضعيف بودن حقوق قانونى مربوط به كسبه

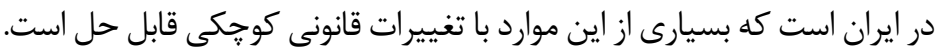

ملاحظات اخلاقى

\section{ييروى از اصول اخلاق يثوهش}

همه اصول اخلاقى در اين مقاله رعايت شده است. شركت كنند أنان اجازه داشتند هر زمان كه مايل بودند

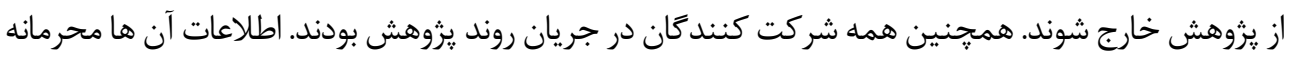
نگَه داشته شد.

$$
\text { حامي مالى }
$$

اين يزوهش هيجگَونه كمك مالى از سازمانيهاى دولتى، خصوصى و غيرانتفاعى دريافت نكرده است.

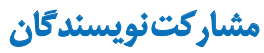

تمام نويسندگان در آمادهسازى اين مقاله مشاركت داشتهاند.

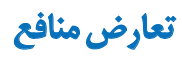

بنابر اظهار نويسندگان، اين مقاله تعارض منافع ندارد. 


\section{References}

Abdollahi, F., Mehrabani, F., \& Basirat M. (2013). [Comparison of the effect of business environment indicators on economic growth: Case study of Iran and member countries of the organization and economic cooperation and development (OECD) (Persian)]. Paper presented at The First National Electronic Conference on Iran's Economy, Isfahan, Iran, 19 December 2013. https://www.civilica.com/Paper-NCFPIE01-NCFPIE01_021.html

Ashrafi, Y., \& Fahimifar, F. (2011). [Investigating the indicators of improving the business environment by emphasizing Iran's position (Persian)]. Economic Journal, 11(11), 7-24. http://ejip.ir/article-1-179-fa.html

Messaoud, B., \& El GhakTeheni, Z. (2014). Business regulations and economic growth: What can be explained? International Strategic Management Review, 2(2), 69-78. [DOI:10.1016/j.ism.2014.03.001]

Doern, R. (2009). Investigates barriers to SME growth and development in transition environments: A critique and suggestions for developing the methodology. International Small Business Journal: Researching Entrepreneurship, 27(3), $275-305$. [DOI:10.1177/0266242609102275]

Ghezel Ayagh, M., Behrooz, M. (2015). [Evaluation of business environment indicators of South Khorasan province using fuzzy logic based on the integrated model of UNIDO business environment and World Bank ten indicators (Persian)]. Paper presented at $2^{\text {nd }}$ National Conference on Improving the Business Environment, Tehran, Iran, 24 August 2015. https://www.sid.ir/Fa/ Seminar/ViewPaper.aspx?ID=39364

Klapper, L. F., \& Love, I. (2011). The impact of business environment reforms on new firm registration. Retrieved from https:// papers.ssrn.com/sol3/papers.cfm?abstract_id=1786802 [DOI:10.2139/ssrn.1786802]

Meydari, A., \& Ghodjani, A. (2008). [Measuring and improving the business environment (Persian)]. Tehran: Iranian Student Book Agency. http://opac.nlai.ir/opac-prod/bibliographic/1241192

Moradi, M. A. (2006). [A Garch model if in flation and inflation uncertionly in Iran (Persian)]. The Economic Research, 6(1), 12145. https://www.sid.ir/fa/journal/ViewPaper.aspx?ID=62462

Nassiri Aghdam, A. (2010). [Reviewing World Bank doing business program for employment generation (Persian)]. Eghtesad va Jame'e, 6(21-22), 35-82. http://ensani.ir/fa/article/218016

Ramezani, M., \& Khadem, A. (2015). [Investigating, monitoring and prioritizing factors affecting the business environment of South Khorasan Province using Analysis Hierarchical Process (AHP) (Persian)]. Paper presented at $2^{\text {nd }}$ National Conference on Improving the Business Environment, Tehran, Iran, 24 August 2015. https://www.sid.ir/Fa/Seminar/ViewPaper. aspx?ID=38667

Stern, N. (2002). A strategy for development. Washington, D. C: World Bank. [DOI:10.1596/0-8213-4980-5] 